\title{
Efficacy of the porcine species in biomedical research
}

\author{
Karina Gutierrez ${ }^{1}$, Naomi Dicks ${ }^{1}$, Werner G. Glanzner ${ }^{1}$, Luis B. Agellon ${ }^{2 \star}$ and \\ Vilceu Bordignon ${ }^{1 *}$
}

${ }^{1}$ Department of Animal Science, McGill University, Sainte-Anne-de-Bellevue, QC, Canada, ${ }^{2}$ School of Dietetics and Human Nutrition, McGill University, Sainte-Anne-de-Bellevue, QC, Canada

Since domestication, pigs have been used extensively in agriculture and kept as companion animals. More recently they have been used in biomedical research, given they share many physiological and anatomical similarities with humans. Recent technological advances in assisted reproduction, somatic cell cloning, stem cell culture,

OPEN ACCESS

Edited by:

Tiago Collares,

Federal University of Pelotas, Brazil

Reviewed by:

Thomas John,

Ludwig Institute for Cancer Research,

Australia

Howard Donninger,

University of Louisville, USA

*Correspondence:

Vilceu Bordignon,

Department of Animal Science, McGill University, Sainte-Anne-de-Bellevue,

QC H9X 3V9, Canada vilceu.bordignon@mcgill.ca; Luis B. Agellon,

School of Dietetics and Human Nutrition, McGill University, Sainte-Anne-de-Bellevue, QC H9X

3V9, Canada

luis.agellon@mcgill.ca

Specialty section:

This article was submitted to Cancer Genetics,

a section of the journal

Frontiers in Genetics

Received: 30 June 2015 Accepted: 04 September 2015 Published: 16 September 2015

Citation:

Gutierrez K, Dicks N, Glanzner WG, Agellon LB and Bordignon V (2015) Efficacy of the porcine species in biomedical research.

Front. Genet. 6:293.

doi: 10.3389/fgene.2015.00293 genome editing, and transgenesis now enable the creation of unique porcine models of human diseases. Here, we highlight the potential applications and advantages of using pigs, particularly minipigs, as indispensable large animal models in fundamental and clinical research, including the development of therapeutics for inherited and chronic disorders, and cancers.

Keywords: Large animal models, biomedical research, swine, pigs, minipigs, clones, transgenics

\section{Introduction}

The first evidence of swine domestication dates back to approximately 7000-9000 years ago (Jones, 1998; McGlone and Pond, 2003; Köhn, 2011; Larson et al., 2011; Figure 1A). China and Europe have been, since domestication, the pig-breeding centers dictating the profile of the pig breeds (Jones, 1998; Amills et al., 2001). The reason for domestication was to provide meat as a source of food protein, which stimulated pig selection and farming (Jones, 1998; Köhn, 2011). Studies have been conducted using genome-wide genotyping and genetic variability to trace the migration, selection, and improvement from ancient wild species to modern swine (Giuffra et al., 2000; Bosse et al., 2014a,b). It is generally accepted that the majority of all modern breeds are derived from the Eurasian wild boar (European and Asian wild boars; Porter, 1993; Bosse et al., 2014b). Although pig selection started just after domestication, it has only been since the mid-20th century that performance has been used as the main tool in the animal selection process (Safranski, 2008). More recently, molecular biology technologies, genome-wide association studies, and next-generation sequencing have been applied to enhance the selection process of domesticated pig breeds (e.g., Duroc, Landrace, Pietrain, Yorkshire, etc.) to further improve traits of high economic value such as feed conversion, meat quality, growth, precocious puberty, and prolificity (Sahana et al., 2013; Tart et al., 2013; Jiang et al., 2014; Sanchez et al., 2014).

The variety of modern pig breeds available today (Buchanan and Stalder, 2011), are a product of human intervention since domestication, but especially during the last century (Figure 1A). Besides breeds specialized for food production, smaller sized breeds (miniature- and micro-pigs) with certain characteristics such as obedience, friendly nature, and cognitive ability have also been selected for the purpose of companion animals. In addition, their use in biomedical research has been increasing considerably in the last years (Figure 1B).

Compared with other animals used in research (e.g., mice, rats, rabbits, and dogs), domestic farm pigs are much larger ( $>300 \mathrm{~kg}$ adult size), therefore, requiring more space and feed, and 


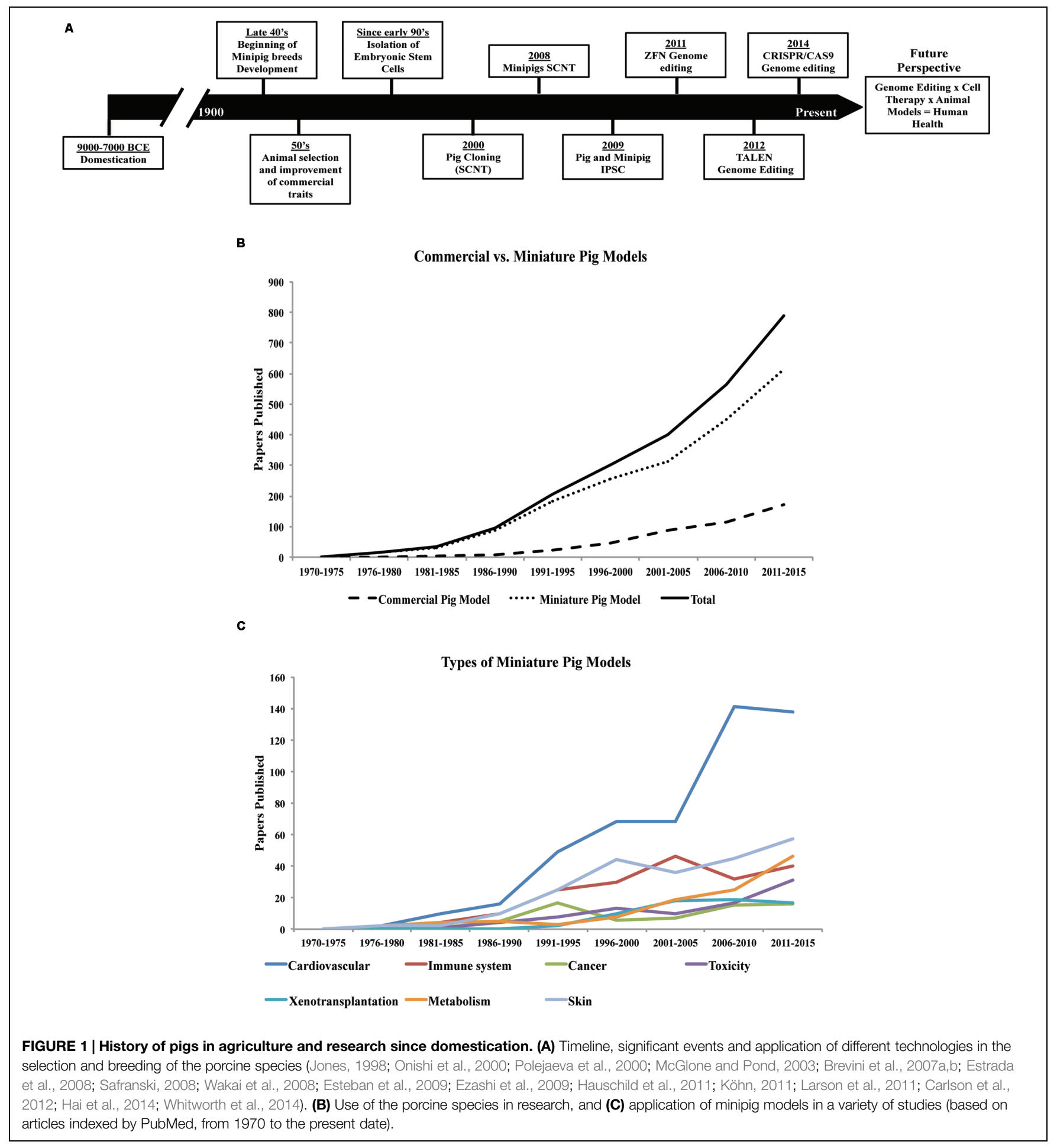

making them harder to handle. Mini- or micro-pigs are hence more desirable for research use. The adult sizes vary among breeds, reaching around $20-30 \mathrm{~kg}$ for a Panepinto micropig to $100 \mathrm{~kg}$ for a Munich minipig (Köhn, 2011). Although many minipig breeds are a product of crossbreeding, some breeds, like the Yucatan pigs, are naturally occurring stocks (Panepinto, 1996; Köhn, 2011). Since the late 1940s, minipigs have been further developed specifically for biomedical research purposes (England and Panepinto, 1986; Köhn, 2011).

There are now several minipig breeds available for use in research (Panepinto, 1996). The main breeds developed in the USA are Yucatan, Sinclair (also known as Minnesota or Hormel miniature pig), Hanford, NIH minipig and Panepinto miniature pig. The minipig breeds developed in Europe 
are Göttingen, Munich, Berlin, Mini-Lewe, Czech-Republic, Vietnamese potbellied and Mini-Sib. In Asia, the breeds include Ohmini, Clawn, Lee Sung, and Chinese minipigs. The Göttingen and Yucatan breeds are the most commonly used minipigs in research, although there is no apparent clear reason for preference. Unlike the Yucatan, a natural breed, the Göttingen minipig was developed specifically for research use. Other breeds are used only by specific research groups, thus limiting their widespread availability in research. Nevertheless, the interest in the use of pigs in biomedical research has been rising over the last 40-45 years (Figure 1B).

\section{Use of Pigs in Biomedical Research}

Biomedical research is broad, spanning studies on underlying disease mechanisms to the evaluation of safety and effectiveness of preventative measures, diagnostic tests, and therapies. Most animal studies in recent times have used the murine species due to their small size, fast reproductive cycles and short lifespan. In addition, the availability of murine embryonic stem cells, fully annotated genome, and facile tools for targeted genetic manipulation have all contributed to the elucidation of gene functions and disease pathophysiology. However, in many cases, mouse models do not adequately represent features of human disorders (Seok et al., 2013). In this regard, animals that better represent human pathophysiology are required. Pigs and humans share many similarities such as size, physiology, anatomy, metabolic profile, and longer lifespan (Panepinto, 1996; Spurlock and Gabler, 2008; Kuzmuk and Schook, 2011; Swindle et al., 2012). For example, pig skin is structurally similar to human skin regarding thickness and spacing between hair follicles, making it useful for studies on wound healing and burn lesions (Sullivan et al., 2001). Pigs also share anatomical and physiological similarities with respect to the renal system, making them valuable for pharmacological studies (Dalgaard, 2014; Huppertz et al., 2015). Pigs can also be useful in the study of nutrient absorption and intestinal transport, as well as the pathogenesis of gastrointestinal diseases (Sangild et al., 2014). All these characteristics contribute to the development of superior models of human conditions (Kuzmuk and Schook, 2011).

The choice between outbred or inbred strains can have a significant impact on research outcomes (Festing, 2014). While, outbred strains may be better suited for quantitative trait loci studies, experiments addressing mechanistic aspects would benefit from the use of inbred strains (Chia et al., 2005). Some minipig breeds are already established for specific applications due to their unique characteristics (Table 1). Pigs have also been used for testing new therapies, devices, and efficacy and safety of new drugs prior to human trials. For instance, a novel endovascular chemotherapy filter, designed to reduce circulatory drug excess in vitro, was successfully tested in pigs (Patel et al., 2014). As well, a new method for pediatric liver transplantation was validated using pigs (Leal et al., 2015). Regarding pharmacokinetic and cytotoxic tests, pigs have been used for testing topical skin formulations (Mitra et al., 2015), and are considered a better choice compared to dogs for the study of drugs that are metabolized by the aldehyde oxidase (AOX1), N-acetyltransferase (NAT1 or NAT2) or cytochrome (CYP2C9-like) enzymes (Dalgaard, 2014).

In general, there is low incidence of naturally occurring pathologies described in pigs. The reason for this is twofold. First, human intervention by way of selective breeding has eliminated genes that increased disease susceptibility. Second, the majority of the domestic farm pigs are slaughtered at a young age $(<$ 6 months old), precluding the detection of late onset diseases such as cancer. On the other hand, Vietnamese potbellied minipigs raised as companion animals do reach old ages. Indeed, a retrospective study found a variety of neoplasms with widespread metastases in these pigs of advanced age ( $\sim 11$ years; Newman and Rohrbach, 2012). The most common malignances found included hepatic and intestinal carcinomas, and uterine and ovarian smooth muscle tumors (Newman and Rohrbach, 2012).

Occurrence of malignant spontaneously regressing melanomas has been described in Sinclair minipigs (Millikan et al., 1974; Oxenhandler et al., 1979). Selective interbreeding, by removing animals with red coat color that do not develop the lesions, increased the frequency of tumor formation in these selected minipigs (Millikan et al., 1974). The tumors appear from birth and culminate in skin depigmentation after tumor regression showing a phenotype similar to human vitiligo (Millikan et al., 1974). Studies conducted in these minipigs have shown decreased telomerase activity during melanoma regression (Pathak et al., 2000), which has also been observed by inhibiting telomerase activity in human melanoma cells (Burchett et al., 2014). Therefore, these minipigs may represent a useful model to study malignant melanomas because the tumors appear spontaneously and then either regress or grow progressively and metastasize similarly to human melanomas (Oxenhandler et al., 1979).

Another example of a naturally occurring condition in pigs is the dwarf phenotype, caused by a single amino acid change in the $\alpha 1$ chain of type X collagen (Nielsen et al., 2000). The COL10A1 gene, which encodes type $\mathrm{X}$ collagen, is expressed in hypertrophic chondrocytes during endochondral ossification. In humans, an amino acid variation in the same position of the type $\mathrm{X}$ collagen protein has been shown to be the cause of Schmid metaphyseal chondrodysplasia (SMCD), a mild skeletal disorder associated with dwarfism (Warman et al., 1993). Since mice lacking type X collagen do not develop abnormalities in long bone development (Rosati et al., 1994), pigs represent a better animal model of human SMCD.

Another naturally occurring disease observed in Yucatan minipigs mimics human ventricular septal defect (VSD; Swindle et al., 1990). The VSD in pigs can be observed in fetal stages similar to the congenital anomaly in humans, and can be used for the study of new methods of diagnosis or therapies (Swindle et al., 1990; Amin et al., 2006).

Despite a number of natural occurring pig phenotypes that resemble human diseases, for most of human pathologies it is difficult to find representative animal models in nature. Thus, manipulation of diet, use of drugs and/or surgeries has been necessary to generate appropriate models. For example, minipig models for Type I diabetes were induced 
TABLE 1 | Characteristics and applications of minipig breeds for the study of human conditions.

\begin{tabular}{|c|c|c|c|c|}
\hline Parameter & Yucatan & Gottingen & Hanford & Sinclair/Minnesota \\
\hline Adult body size (kg) & $70-83$ & $\sim 45$ & 80-95 & $55-70$ \\
\hline Average litter size & 6 & 6.5 & 6.7 & 7.2 \\
\hline Age to puberty (months) & $4-6$ & $3-5$ & $4-6$ & $4-6$ \\
\hline Genetic background & Purebred & Outbred & Outbred & Outbred \\
\hline Cloning & $\begin{array}{l}\text { somatic cell nuclear transfer } \\
\text { (SCNT; Estrada et al., 2008) }\end{array}$ & SCNT (Wakai et al., 2008) & Information not available & SCNT (Do et al., 2012) \\
\hline Transgenics & $\begin{array}{l}\text { Homologous recombination } \\
\text { BRCA1 (breast cancer } \\
\text { susceptibility gene 1) - } \\
\text { gene knockout by rAAV - } \\
\text { model for breast cancer } \\
\text { (Luo et al., 2011, 2012)* } \\
\text { Introduction of missense } \\
\text { mutation via rAAV - TP53 } \\
\text { gene - cancer cells (Sieren } \\
\text { et al., 2014) } \\
\text { Introduction of nonsense } \\
\text { mutation via rAAV - SCN5A } \\
\text { gene - cardiac arrhythmia } \\
\text { (Park et al., 2015) }\end{array}$ & $\begin{array}{l}\text { Homologous recombination } \\
\text { BRCA1 (breast cancer } \\
\text { susceptibility gene 1) - } \\
\text { gene knockout by rAAV - } \\
\text { model for breast cancer } \\
\text { (Luo et al., 2012) }{ }^{\dagger} \\
\text { rAAV vectors encoding } \\
\text { GFP (Kornum et al., 2010) }\end{array}$ & Information not available & $\begin{array}{l}\text { ZFN - mono and biallelic } \\
\text { knockout pigs - CMAH } \\
\text { gene - xenoantigen } \\
\text { involved in the rejection } \\
\text { phenomenon (Kwon et al., } \\
\text { 2013) } \\
\text { TALEN - biallelic modified } \\
\text { pigs - RAG2 gene - } \\
\text { immune system (Lee et al., } \\
\text { 2014) }\end{array}$ \\
\hline Applications & $\begin{array}{l}\text { Wound healing (Eggleston } \\
\text { et al., 2000) } \\
\text { Cardiovascular model for } \\
\text { ventricular septal defect } \\
\text { (VSD; Swindle et al., 1990) } \\
\text { Metabolic Disorder (Phillips } \\
\text { et al., 1982) }\end{array}$ & $\begin{array}{l}\text { Toxicity Studies (Bollen and } \\
\text { Ellegaard, 1997; van Mierlo } \\
\text { et al., 2013) } \\
\text { Skin pharmacokinetics } \\
\text { tests (Mitra et al., 2015) } \\
\text { Metabolic Syndrome } \\
\text { (Johansen et al., 2001) } \\
\text { Neurodegenerative } \\
\text { disease - Parkinson Model } \\
\text { (Bjarkam et al., 2008) } \\
\text { Obesity (Christoffersen } \\
\text { et al., 2013) } \\
\text { Heart failure (Schuleri et al., } \\
\text { 2008) }\end{array}$ & $\begin{array}{l}\text { Dermal studies - toxicology } \\
\text { (Leigh et al., 2012) } \\
\text { Wound healing (Reger } \\
\text { et al., 1999) } \\
\text { Surgery training (Purohit } \\
\text { et al., 1993) } \\
\text { Tests of new therapies in } \\
\text { tissue regeneration (Van } \\
\text { Dyke et al., 2015) }\end{array}$ & $\begin{array}{l}\text { Oncology (malignant } \\
\text { spontaneously regression } \\
\text { melanoma; Oxenhandler } \\
\text { et al., 1979) } \\
\text { Dermatology - skin } \\
\text { depigmentation (Millikan } \\
\text { et al., 1974) } \\
\text { Models of human } \\
\text { alcoholism (Dexter et al., } \\
\text { 1976) } \\
\text { Pediatric hypothyroidism } \\
\text { (Tank et al., 2013) }\end{array}$ \\
\hline
\end{tabular}

*The animals died 18 days after birth.

${ }^{\dagger}$ Cloned animals were not yet born at the time of publication.

via administration of streptozotocin or alloxan to selectively destroy insulin-producing cells (Phillips et al., 1980; Larsen et al., 2002). High-energy diets in young minipigs lead to the development of obesity and metabolic syndromes, with increased visceral fat deposition, glucose intolerance, decreased insulin sensitivity, and higher levels of blood cholesterol and triglycerides, which progress to Type 2 Diabetes mellitus (Xi et al., 2004; Neeb et al., 2010; Koopmans and Schuurman, 2015). Other chemicals have been used to induce cellular dysregulation and damage in pigs including the administration of $N$-nitrosodiethylamine to produce a liver cancer model (Li et al., 2006).

\section{Use of Engineered Pigs in Biomedical Research}

Genetically modified animals have been instrumental in advancing our understanding of gene function and significance of inappropriate gene expression in metabolic malfunction in mammals. Genome editing holds great promise in generating these models, and has already permitted the rapid development of new pig models of several human diseases (Rogers et al., 2008; Prather et al., 2013; Hai et al., 2014; Dicks, 2015).

The cystic fibrosis (CF) model is an example of genetically engineered pigs created by targeted inactivation of the cystic fibrosis transmembrane conductance regulator (CFTR) gene (Rogers et al., 2008). The resulting pigs exhibit clinical features and disease progression consistent with those observed in CF infants. In contrast, inactivation of the CFTR gene in mice did not produce the comorbidities typically observed in human CF patients (Snouwaert et al., 1992).

Advanced reproductive technologies, such as somatic cell nuclear transfer (SCNT), can now be routinely applied to large animal species, including minipigs. Minipigs of different breeds have been cloned from different cell types, including genetically modified cells (Estrada et al., 2008; Kurome et al., 2008; Wakai et al., 2008; Zhao et al., 2009). In addition SCNT offers the possibility of creating isogenic and immunocompatible animals from the same cell line. Importantly, models of severe disorders can be generated from engineered cultured cells without the need of breeding sick animals. The sequencing of the pig 
genome is another key development in the production of genemodified pigs in the post-genomic era (Schook et al., 2015a). Genome editing techniques, including zinc finger nucleases (ZFN), transcription activator-like effector nucleases (TALEN), and clustered, regularly interspaced, short palindromic repeats (CRISPR) together with CRISPR associated (Cas) nucleases (CRISPR/Cas), now allow the precise manipulation of gene sequences in germ, embryonic and somatic cells (Hauschild et al., 2011; Carlson et al., 2012; Cong et al., 2013; Hai et al., 2014; Whitworth et al., 2014; Dicks, 2015). Among these methods, the CRISPR/Cas9 system is emerging as the method of choice because it permits gene editing to be accomplished in only one step by injecting both the specific guide RNAs and endonuclease into zygotes (Hai et al., 2014; Whitworth et al., 2014).

Another example of human disease that has the potential to be studied in genetically engineered pigs is heart arrhythmias (Park et al., 2015). Mutations in the SCN5A gene, which encodes a subunit of the cardiac sodium channel $\mathrm{Na}_{\mathrm{v}} 1.5$ required for excitability and conduction in the myocardium, were found in patients with Bruguda syndrome (Hedley et al., 2009). SCN5 $A^{E 558 X /+}$ engineered Yucatan minipigs with reduced expression of the sodium channel $\mathrm{Na}_{\mathrm{v}} 1.5$ have been created and these animals exhibit conduction abnormalities and susceptibility to ventricular arrhythmias (Park et al., 2015). There has also been considerable interest in genetically modified pig strains suitable for xenotransplantation. Most research into the development of appropriate xenotransplantation strains focused on addressing hyperacute rejection, which is initiated rapidly and involves preformed natural human antibodies and the complement system (Cooper et al., 2002). This has been possible by targeting cell surface antigens such as $\alpha-1,3$ galactosyltransferase (Miyagawa et al., 2001; Lai et al., 2002; Phelps et al., 2003; Takahagi et al., 2005) or complement regulatory proteins such as human decay accelerating factor (Murakami et al., 2002). The pigs made deficient of $\alpha-1,3$ galactosyltransferase have contributed to the reduction of immunogenicity of donor tissue/organs (Phelps et al., 2003). Transgenic pigs expressing antibodies against cytotoxic T-cell lymphocyte antigen receptor, a cell-mediated immune response suppressor, were also developed (Phelps et al., 2009).

A pig model for the human familial adenomatous polyposis was generated by inactivation of the adenomatous polyposis coli (APC) gene (Flisikowska et al., 2012). Mice lacking the APC gene exhibit non-metastatic neoplasias only in the small intestine (Su et al., 1992). However, the pig model of colon and rectal cancer reproduces the human features of the disease, which includes the development of polyps spread along the whole large bowel in young animals. A candidate gene for the development of breast and ovarian cancer models is the breast cancer-associated gene 1 (BRCA1), which has been manipulated in both Yucatan and Göttingen cells, but lines of modified minipigs remain to be produced (Luo et al., 2011, 2012). The TP53 gene, which encodes the tumor suppressor protein p53 and is the most commonly observed suppressed gene in human tumors, was found to be mutated in Li-Fraumeni patients having increased risk to develop multiple types of cancers (Gonzalez et al., 2009). Suppression of p53 in mesenchymal stem cells derived from pig bone marrow exhibits chemoresistance in vitro (Leuchs et al., 2012). Mutation of TP53 gene in Yucatan minipigs resulted in development of lymphomas and osteogenic tumors (Sieren et al., 2014). More recently, a new engineered pig strain termed "oncopig" was developed, which promises inducible formation of a wide variety of cancers that are potentially novel platforms for research and therapeutics development (Schook et al., 2015b). These examples illustrate the potential of genetically engineered pigs as robust models for the study of human pathologies that are not well represented in small laboratory animal species.

\section{Improving the Usefulness of Pigs in Biomedical Research}

Rodents have been the choice animal model for basic research, but are not always suitable for translational research due to marked differences in size, lifespan as well as metabolic, anatomical, and physiological discrepancies. On the other hand, the pig is more closely related to humans in terms of these parameters (Swindle et al., 2012) and, therefore, is better suited for recapitulation of human diseases. Indeed, the use of the pig in translational research is increasingly gaining acceptance (Figure 1C). Dogs and non-human primates have traditionally been used for this purpose, but rising ethical concerns have reduced their favor and increased demand for alternatives (Swindle et al., 2012). The number of peer-reviewed papers describing the use of pigs as biomedical models has risen eightfold over the past 30 years (Figure 1B). Already, the pig has become well established in many areas of research and training. For instance, in the past 20 years the pig has replaced the dog as a model for surgical training and has also gained FDA approval for the testing of surgical implantation devices intended for human use (Swindle et al., 2012; Schook et al., 2015a). Minipig models, which are much smaller in size compared to the domestic farm breeds, offer lower operating costs compared to other large animal models and also reduce the concern of ethical acceptance given the already widespread use of pigs in agriculture (Bollen and Ellegaard, 1997; Swindle et al., 2012).

Pigs offer many exciting applications, including stem cell research, tissue engineering and xenotransplantation. Although incredible advances in transgenic pigs harboring various engineered alterations designed to minimize graft versus host rejection (Lai et al., 2002; Phelps et al., 2003, 2009; Klose et al., 2005; Takahagi et al., 2005; Hauschild et al., 2011; Petersen et al., 2011; Jeong et al., 2013), much work remains to be accomplished since multiple genes need to be manipulated given the various types of tissue rejection reactions (Takahagi et al., 2005; Whyte and Prather, 2011; Jeong et al., 2013). Porcine induced pluripotent stem cells (iPSCs) have been produced (Esteban et al., 2009) and chimeric pigs were generated using iPSC (West et al., 2010, 2011). This is highly relevant since study of porcine iPSCs have eventual human applications (Esteban et al., 2009), such as cell-based therapies. However, the mechanisms of cellular reprogramming, directed cell differentiation and species-specific cell culture requirements necessitate further investigation (Ezashi et al., 2012). The 
International Society for Stem Cell Research has indicated in their guidelines for translational use that validation must occur in both small and large animal models (Aigner et al., 2010). Tissue repair is another potential application of engineered pig models. Cartilage tissue grafts have been created using chondrocytes isolated from infant minipigs (Deponti et al., 2014), and mandibular condyle grafts have been generated from Yucatan minipig adipose-derived mesenchymal stem cells (Abukawa et al., 2003). There has also been successful regeneration of bone defects using engineered bone graft tissues in minipig models (Gröger et al., 2003). If custom donor transgenic minipig strains can be created, this could open the doors to other engineered tissue replacements for human uses. For example, the use of blastocyst complementation and pluripotent stem cells has been applied to direct the development of otherwise missing organs in pigs (Matsunari et al., 2013). This has increased the hope that it may one day be possible to create non-immunogenic donor organs in pigs using human iPSCs (Matsunari et al., 2013; Feng et al., 2015). Finally, similarities in the porcine and human immune system have sparked interest in vaccine development and efficacy testing in pigs (Meurens et al., 2012).

The completion of the porcine genome project in 2012 has further facilitated the use of pigs in research. Data from this project has enabled the comparative analysis of genetic sequences and development of the necessary tools to create and validate targeted genetic alterations in the porcine genome (Gun and Kues, 2014; Schook et al., 2015a). In addition, the development of RNASeq technology has facilitated transcriptome analysis, which further improves our ability to identify important targets related to certain phenotypic traits (Ropka-Molik et al., 2014). Other recent achievements in the pig include the use of inducible or conditional systems to control transgene expression (Kues et al., 2006; Klymiuk et al., 2012), and tissue-specific expression of the Cre recombinase (Li et al., 2009; Luo et al., 2014). These advances will ensure the continued development of various pig strains for research, similar to what has already been accomplished in mice.

\section{References}

Abukawa, H., Terai, H., Hannouche, D., Vacanti, J. P., Kaban, L. B., and Troulis, M. J. (2003). Formation of a mandibular condyle in vitro by tissue engineering. J. Oral Maxillofac. Surg. 61, 94-100. doi: 10.1053/joms.2003. 50015

Aigner, B., Renner, S., Kessler, B., Klymiuk, N., Kurome, M., Wunsch, A., et al. (2010). Transgenic pigs as models for translational biomedical research. J. Mol. Med. (Berl.) 88, 653-664. doi: 10.1007/s00109-010-0610-9

Amills, M., Clop, A., Ramírez, O., and Pérez-Enciso, M. (2010). “Origin and genetic diversity of pig breeds," in Encyclopedia of Life Sciences (eLS) (Chichester: John Wiley \& Sons Ltd). doi: 10.1002/9780470015902.a0022884

Amin, Z., Woo, R., Danford, D. A., Froemming, S. E., Reddy, V. M., Lof, J., et al. (2006). Robotically assisted perventricular closure of perimembranous ventricular septal defects: preliminary results in Yucatan pigs. J. Thorac. Cardiovasc. Surg. 131, 427-432. doi: 10.1016/j.jtcvs.2005.10.034

Bjarkam, C. R., Nielsen, M. S., Glud, A. N., Rosendal, F., Mogensen, P., Bender, D., et al. (2008). Neuromodulation in a minipig MPTP model of Parkinson disease. Br. J. Neurosurg. 22(Suppl. 1), S9-S12. doi: 10.1080/02688690802448285

Bollen, P., and Ellegaard, L. (1997). The Gottingen minipig in pharmacology and toxicology. Pharmacol. Toxicol. 80(Suppl. 2), 3-4. doi: 10.1111/j.16000773.1997.tb01980.x

\section{Summary}

It is clear that the use of the pig as a biomedical model is increasingly gaining approval due to physiopathological similarities with humans. However, some obstacles remain to be overcome in order to realize the full potential of the porcine species in developing new diagnostic and therapeutic approaches. Despite the sequencing of the porcine genome, full annotation has yet to be completed. This is essential to facilitate interrogation of the pig genome and investigation of less characterized genes. Efforts to develop a complete porcine proteome map as well as epigenome map are currently underway (Meurens et al., 2012; Schook et al., 2015a). These databases are necessary to understand disease pathogenesis (Meurens et al., 2012; Schook et al., 2015a). Moreover, the availability of both inbred and outbred breeds of minipigs extends the utility of these species as a viable large animal model. Continuing refinements and adaptation of technologies for genome editing, cell/tissue-specific gene targeting strategies, stem cells and somatic cell cloning will further facilitate the creation of specialized pig strains for biomedical research.

\section{Acknowledgments}

Research in our laboratories is funded by grants from the Natural Sciences and Engineering Research Council of Canada (to VB and to LA). KG is supported by a scholarship from the Science without Borders Program of the Brazilian Coordination for the Improvement of Higher Education Personnel (CAPES). WG is supported by a scholarship from the Brazilian National Council for Scientific and Technological Development (CNPq). ND is supported by an Alexander Graham Bell Canada Graduate Scholarship from the Natural Sciences and Engineering Research Council of Canada.

Bosse, M., Madsen, O., Megens, H. J., Frantz, L. A., Paudel, Y., Crooijmans, R. P., et al. (2014a). Hybrid origin of European commercial pigs examined by an in-depth haplotype analysis on chromosome 1. Front. Genet. 5:442. doi: 10.3389/fgene.2014.00442

Bosse, M., Megens, H.-J., Frantz, L. A. F., Madsen, O., Larson, G., Paudel, Y., et al. (2014b). Genomic analysis reveals selection for Asian genes in European pigs following human-mediated introgression. Nat. Commun. 5:4392. doi: 10.1038/ncomms5392

Brevini, T. A., Antonini, S., Cillo, F., Crestan, M., and Gandolfi, F. (2007a). Porcine embryonic stem cells: facts, challenges and hopes. Theriogenology 68(Suppl. 1), S206-S213. doi: 10.1016/j.theriogenology.2007. 05.043

Brevini, T. A., Tosetti, V., Crestan, M., Antonini, S., and Gandolfi, F. (2007b). Derivation and characterization of pluripotent cell lines from pig embryos of different origins. Theriogenology 67, 54-63. doi: 10.1016/j.theriogenology.2006.09.019

Buchanan, D. S., and Stalder, K. (2011). "Breeds of pigs," in The Genetics of the Pig, eds M. F. Rothschild and A. Ruvinsky (Cambridge, MA: CAB International).

Burchett, K. M., Yan, Y., and Ouellette, M. M. (2014). Telomerase inhibitor Imetelstat (GRN163L) limits the lifespan of human pancreatic cancer cells. PLoS ONE 9:e85155. doi: 10.1371/journal.pone.00 85155 
Carlson, D. F., Tan, W., Lillico, S. G., Stverakova, D., Proudfoot, C., Christian, M., et al. (2012). Efficient TALEN-mediated gene knockout in livestock. Proc. Natl. Acad. Sci. U.S.A. 109, 17382-17387. doi: 10.1073/pnas.1211446109

Chia, R., Achilli, F., Festing, M. F., and Fisher, E. M. (2005). The origins and uses of mouse outbred stocks. Nat. Genet. 37, 1181-1186. doi: 10.1038/ng1665

Christoffersen, B., Golozoubova, V., Pacini, G., Svendsen, O., and Raun, K. (2013). The young Gottingen minipig as a model of childhood and adolescent obesity: influence of diet and gender. Obesity (Silver Spring) 21, 149-158. doi: 10.1002/oby.20249

Cong, L., Ran, F. A., Cox, D., Lin, S., Barretto, R., Habib, N., et al. (2013). Multiplex genome engineering using CRISPR/Cas systems. Science 339, 819-823. doi: $10.1126 /$ science. 1231143

Cooper, D. K., Gollackner, B., and Sachs, D. H. (2002). Will the pig solve the transplantation backlog? Annu. Rev. Med. 53, 133-147. doi: 10.1146/annurev.med.53.082901.103900

Dalgaard, L. (2014). Comparison of minipig, dog, monkey and human drug metabolism and disposition. J. Pharmacol. Toxicol. Methods 74, 80-92. doi: 10.1016/j.vascn.2014.12.005

Deponti, D., Di Giancamillo, A., Gervaso, F., Domenicucci, M., Domeneghini, C., Sannino, A., et al. (2014). Collagen scaffold for cartilage tissue engineering: the benefit of fibrin glue and the proper culture time in an infant cartilage model. Tissue Eng. Part A 20, 1113-1126. doi: 10.1089/ten.TEA.2013.0171

Dexter, J. D., Tumbleson, M. E., Hutcheson, D. P., and Middleton, C. C. (1976). Sinclair(S-1) miniature swine as a model for the study of human alcoholism. Ann. N. Y. Acad. Sci. 273, 188-193. doi: 10.1111/j.1749-6632.1976.tb52881.x

Dicks, N. (2015). "Somatic cell nuclear transfer and the creation of transgenic large animal models," in Somatic Genome Manipulation: Advances, Methods and Applications, eds D. J. Donnelly, X.-Q. Li and T. G. Jensen (New York: Springer), 123-143.

Do, M., Jang, W. G., Hwang, J. H., Jang, H., Kim, E. J., Jeong, E. J., et al. (2012). Inheritance of mitochondrial DNA in serially recloned pigs by somatic cell nuclear transfer (SCNT). Biochem. Biophys. Res. Commun. 424, 765-770. doi: 10.1016/j.bbrc.2012.07.031

Eggleston, T. A., Roach, W. P., Mitchell, M. A., Smith, K., Oler, D., and Johnson, T. E. (2000). Comparison of two porcine (Sus scrofa domestica) skin models for in vivo near-infrared laser exposure. Comp. Med. 50, 391-397.

England, D. C., and Panepinto, L. M. (1986). "Conceptual and operational history of the development of miniature swine," in Swine in Biomedical Research, ed. M. E. Tumbleson (New York, NY: Plenum Press).

Esteban, M. A., Xu, J., Yang, J., Peng, M., Qin, D., Li, W., et al. (2009). Generation of induced pluripotent stem cell lines from Tibetan miniature pig. J. Biol. Chem. 284, 17634-17640. doi: 10.1074/jbc.M109.008938

Estrada, J. L., Collins, B., York, A., Bischoff, S., Sommer, J., Tsai, S., et al. (2008). Successful cloning of the Yucatan minipig using commercial/occidental breeds as oocyte donors and embryo recipients. Cloning Stem Cells 10, 287-296. doi: 10.1089/clo.2008.0005

Ezashi, T., Telugu, B. P., Alexenko, A. P., Sachdev, S., Sinha, S., and Roberts, R. M. (2009). Derivation of induced pluripotent stem cells from pig somatic cells. Proc. Natl. Acad. Sci. U.S.A. 106, 10993-10998. doi: 10.1073/pnas.0905284106

Ezashi, T., Telugu, B. P., and Roberts, R. M. (2012). Induced pluripotent stem cells from pigs and other ungulate species: an alternative to embryonic stem cells? Reprod. Domest. Anim. 47(Suppl. 4), 92-97. doi: 10.1111/j.14390531.2012.02061.x

Feng, W., Dai, Y., Mou, L., Cooper, D. K., Shi, D., and Cai, Z. (2015). The Potential of the Combination of CRISPR/Cas9 and Pluripotent Stem Cells to Provide Human Organs from Chimaeric Pigs. Int. J. Mol. Sci. 16, 6545-6556. doi: 10.3390/ijms16036545

Festing, M. F. (2014). Evidence should trump intuition by preferring inbred strains to outbred stocks in preclinical research. ILAR J. 55, 399-404. doi: 10.1093/ilar/ilu036

Flisikowska, T., Merkl, C., Landmann, M., Eser, S., Rezaei, N., Cui, X., et al. (2012). A porcine model of familial adenomatous polyposis. Gastroenterology 143, e1171-e1177. doi: 10.1053/j.gastro.2012.07.110

Giuffra, E., Kijas, J. M., Amarger, V., Carlborg, O., Jeon, J. T., and Andersson, L. (2000). The origin of the domestic pig: independent domestication and subsequent introgression. Genetics 154, 1785-1791.

Gonzalez, K. D., Noltner, K. A., Buzin, C. H., Gu, D., Wen-Fong, C. Y., Nguyen, V. Q., et al. (2009). Beyond Li Fraumeni Syndrome: clinical characteristics of families with p53 germline mutations. J. Clin. Oncol. 27, 1250-1256. doi: 10.1200/JCO.2008.16.6959

Gröger, A., Kläring, S., Merten, H.-A., Holste, J., Kaps, C., and Sittinger, M. (2003). Tissue engineering of bone for mandibular augmentation in immunocompetent minipigs: preliminary study. Scand. J. Plastic Reconstruct. Surg. Hand Surg. 37, 129-133. doi: 10.1080/02844310310007728

Gun, G., and Kues, W. A. (2014). Current progress of genetically engineered pig models for biomedical research. Biores. Open. Access. 3, 255-264. doi: 10.1089/biores.2014.0039

Hai, T., Teng, F., Guo, R., Li, W., and Zhou, Q. (2014). One-step generation of knockout pigs by zygote injection of CRISPR/Cas system. Cell Res. 24, 372-375. doi: $10.1038 / \mathrm{cr} .2014 .11$

Hauschild, J., Petersen, B., Santiago, Y., Queisser, A. L., Carnwath, J. W., LucasHahn, A., et al. (2011). Efficient generation of a biallelic knockout in pigs using zinc-finger nucleases. Proc. Natl. Acad. Sci. U.S.A. 108, 12013-12017. doi: $10.1073 /$ pnas. 1106422108

Hedley, P. L., Jorgensen, P., Schlamowitz, S., Moolman-Smook, J., Kanters, J. K., Corfield, V. A., et al. (2009). The genetic basis of Brugada syndrome: a mutation update. Hum. Mutat. 30, 1256-1266. doi: 10.1002/humu.21066

Huppertz, N., Tolba, R., and Grosse, J. (2015). Micturition in Gottingen minipigs: first reference in vivo data for urological research and review of literature. Lab. Anim. doi: 10.1177/0023677215570993 [Epub ahead of print].

Jeong, Y. H., Park, C. H., Jang, G. H., Jeong, Y. I., Hwang, I. S., Jeong, Y. W., et al. (2013). Production of multiple transgenic Yucatan miniature pigs expressing human complement regulatory factors, human CD55. CD59, and H-transferase genes. PLoS ONE 8:e63241. doi: 10.1371/journal.pone.0063241

Jiang, J., Wang, J., Wang, H., Zhang, Y., Kang, H., Feng, X., et al. (2014). Global copy number analyses by next generation sequencing provide insight into pig genome variation. BMC Genomics 15:593. doi: 10.1186/1471-2164-15-593

Johansen, T., Hansen, H. S., Richelsen, B., and Malmlof, R. (2001). The obese Gottingen minipig as a model of the metabolic syndrome: dietary effects on obesity, insulin sensitivity, and growth hormone profile. Comp. Med. 51, $150-155$.

Jones, G. F. (1998). "Genetic aspects of domestication, common breeds and their origin," in The Genetics of the Pig, eds M. F. Rothschild and A. Ruvinsky (New York: CAB International).

Klose, R., Kemter, E., Bedke, T., Bittmann, I., Keler, B., Endres, R., et al. (2005). Expression of biologically active human TRAIL in transgenic pigs. Transplantation 80, 222-230. doi: 10.1097/01.tp.0000164817.59006.c2

Klymiuk, N., Bocker, W., Schonitzer, V., Bahr, A., Radic, T., Frohlich, T., et al. (2012). First inducible transgene expression in porcine large animal models. FASEB J. 26, 1086-1099. doi: 10.1096/fj.11-185041

Köhn, F. (2011). "History and development of miniature, micro- and minipigs," in The Minipig in Biomedical Research, eds P. A. Mcanulty, A. D. Dayan, N. C. Ganderup and K. L. Hastings (Boca Raton, FL: CRC Press).

Koopmans, S. J., and Schuurman, T. (2015). Considerations on pig models for appetite, metabolic syndrome and obese type 2 diabetes: from food intake to metabolic disease. Eur. J. Pharmacol. 759, 231-239. doi: 10.1016/j.ejphar.2015.03.044

Kornum, B. R., Stott, S. R., Mattsson, B., Wisman, L., Ettrup, A., Hermening, S., et al. (2010). Adeno-associated viral vector serotypes 1 and 5 targeted to the neonatal rat and pig striatum induce widespread transgene expression in the forebrain. Exp. Neurol. 222, 70-85. doi: 10.1016/j.expneurol.2009. 12.009

Kues, W. A., Schwinzer, R., Wirth, D., Verhoeyen, E., Lemme, E., Herrmann, D., et al. (2006). Epigenetic silencing and tissue independent expression of a novel tetracycline inducible system in double-transgenic pigs. FASEB J. 20, 1200-1202. doi: 10.1096/fj.05-5415fje

Kurome, M., Ishikawa, T., Tomii, R., Ueno, S., Shimada, A., Yazawa, H., et al. (2008). Production of transgenic and non-transgenic clones in miniature pigs by somatic cell nuclear transfer. J. Reprod. Dev. 54, 156-163. doi: 10.1262/jrd.20038

Kuzmuk, K. N., and Schook, L. B. (2011). "Pig as a model for biomedical sciences," in The Genetics of the Pig, eds M. F. Rothschild and A. Ruvinsky (Cambridge, MA: CAB International).

Kwon, D. N., Lee, K., Kang, M. J., Choi, Y. J., Park, C., Whyte, J. J., et al. (2013). Production of biallelic CMP-Neu5Ac hydroxylase knock-out pigs. Sci. Rep. 3, 1981. doi: 10.1038/srep01981 
Lai, L., Kolber-Simonds, D., Park, K. W., Cheong, H. T., Greenstein, J. L., Im, G. S., et al. (2002). Production of alpha-1,3-galactosyltransferase knockout pigs by nuclear transfer cloning. Science 295, 1089-1092. doi: 10.1126/science.1068228

Larsen, M. O., Wilken, M., Gotfredsen, C. F., Carr, R. D., Svendsen, O., and Rolin, B. (2002). Mild streptozotocin diabetes in the Gottingen minipig. A novel model of moderate insulin deficiency and diabetes. Am. J. Physiol. Endocrinol. Metab. 282, E1342-E1351. doi: 10.1152/ajpendo.0056 4.2001

Larson, G., Cucchi, T., and Dobney, K. (2011). "Genetic aspects of pig domestication," in The Genetics of the Pig, eds M. F. Rothschild and A. Ruvinsky (Cambridge, MA: CAB International).

Leal, A. J., Tannuri, A. C., Belon, A. R., Guimaraes, R. R., Coelho, M. C., Goncalves Jde, O., et al. (2015). Effects of ischemic preconditioning in a pig model of large-for-size liver transplantation. Clinics (Sao Paulo) 70, 126-135. doi: 10.6061/clinics/2015(02)10

Lee, K., Kwon, D. N., Ezashi, T., Choi, Y. J., Park, C., Ericsson, A. C., et al. (2014). Engraftment of human iPS cells and allogeneic porcine cells into pigs with inactivated RAG2 and accompanying severe combined immunodeficiency. Proc. Natl. Acad. Sci. U.S.A. 111, 7260-7265. doi: 10.1073/pnas.1406376111

Leigh, H., Forbes, P. D., Lawson, C., Kim, D. Y., White, D., Brown, L. D., et al. (2012). Miniature swine model of phototoxicity testing. Photodermatol. Photoimmunol. Photomed. 28, 34-41. doi: 10.1111/j.1600-0781.2011.00633.x

Leuchs, S., Saalfrank, A., Merkl, C., Flisikowska, T., Edlinger, M., Durkovic, M., et al. (2012). Inactivation and inducible oncogenic mutation of p53 in gene targeted pigs. PLoS ONE 7:e43323. doi: 10.1371/journal.pone.0043323

Li, L., Pang, D., Wang, T., Li, Z., Chen, L., Zhang, M., et al. (2009). Production of a reporter transgenic pig for monitoring Cre recombinase activity. Biochem. Biophys. Res. Commun. 382, 232-235. doi: 10.1016/j.bbrc.2009.02.146

Li, X., Zhou, X., Guan, Y., Wang, Y. X., Scutt, D., and Gong, Q. Y. (2006). $\mathrm{N}$-nitrosodiethylamine-induced pig liver hepatocellular carcinoma model: radiological and histopathological studies. Cardiovasc. Intervent. Radiol. 29, 420-428. doi: 10.1007/s00270-005-0099-8

Luo, W., Li, Z., Huang, Y., Han, Y., Yao, C., Duan, X., et al. (2014). Generation of AQP2-Cre transgenic mini-pigs specifically expressing Cre recombinase in kidney collecting duct cells. Transg. Res. 23, 365-375. doi: 10.1007/s11248-0139774-8

Luo, Y., Bolund, L., and Sorensen, C. B. (2012). Pig gene knockout by rAAV-mediated homologous recombination: comparison of BRCA1 gene knockout efficiency in Yucatan and Gottingen fibroblasts with slightly different target sequences. Transg. Res. 21, 671-676. doi: 10.1007/s11248-0119563-1

Luo, Y., Li, J., Liu, Y., Lin, L., Du, Y., Li, S., et al. (2011). High efficiency of BRCA1 knockout using rAAV-mediated gene targeting: developing a pig model for breast cancer. Transg. Res. 20, 975-988. doi: 10.1007/s11248-010-9472-8

Matsunari, H., Nagashima, H., Watanabe, M., Umeyama, K., Nakano, K., Nagaya, M., et al. (2013). Blastocyst complementation generates exogenic pancreas in vivo in apancreatic cloned pigs. Proc. Natl. Acad. Sci. U.S.A. 110, 4557-4562. doi: 10.1073/pnas.1222902110

McGlone, J., and Pond, W. (2003). Pig Production: Biological Principles and Applications. Florence: Thomson - Delmar Learning.

Meurens, F., Summerfield, A., Nauwynck, H., Saif, L., and Gerdts, V. (2012). The pig: a model for human infectious diseases. Trends Microbiol. 20, 50-57. doi: 10.1016/j.tim.2011.11.002

Millikan, L. E., Boylon, J. L., Hook, R. R., and Manning, P. J. (1974). Melanoma in Sinclair swine: a new animal model. J. Invest. Dermatol. 62, 20-30. doi: 10.1111/1523-1747.ep12676714

Mitra, A., Leyes, A., Manser, K., Roadcap, B., Mestre, C., Tatosian, D., et al. (2015). Use of minipig skin biopsy model as an innovative tool to design topical formulation to achieve desired pharmacokinetics in humans. J. Pharm. Sci. 104, 1701-1708. doi: 10.1002/jps.24383

Miyagawa, S., Murakami, H., Takahagi, Y., Nakai, R., Yamada, M., Murase, A., et al. (2001). Remodeling of the major pig xenoantigen by $\mathrm{N}$-acetylglucosaminyltransferase III in transgenic pig. J. Biol. Chem. 276, 39310-39319. doi: 10.1074/jbc.M104359200

Murakami, H., Nagashima, H., Takahagi, Y., Miyagawa, S., Fujimura, T., Toyomura, K., et al. (2002). Transgenic pigs expressing human decayaccelerating factor regulated by porcine MCP gene promoter. Mol. Reprod. Dev. 61, 302-311. doi: $10.1002 / \mathrm{mrd} .10043$
Neeb, Z. P., Edwards, J. M., Alloosh, M., Long, X., Mokelke, E. A., and Sturek, M. (2010). Metabolic syndrome and coronary artery disease in Ossabaw compared with Yucatan swine. Comp. Med. 60, 300-315.

Newman, S. J., and Rohrbach, B. (2012). Pot-bellied pig neoplasia: a retrospective case series (2004-2011). J. Vet. Diagn. Invest. 24, 1008-1013. doi: $10.1177 / 1040638712452725$

Nielsen, V. H., Bendixen, C., Arnbjerg, J., Sorensen, C. M., Jensen, H. E., Shukri, N. M., et al. (2000). Abnormal growth plate function in pigs carrying a dominant mutation in type X collagen. Mamm. Genome 11, 1087-1092. doi: $10.1007 / \mathrm{s} 003350010212$

Onishi, A., Iwamoto, M., Akita, T., Mikawa, S., Takeda, K., Awata, T., et al. (2000). Pig cloning by microinjection of fetal fibroblast nuclei. Science $289,1188-1190$. doi: 10.1126/science.289.5482.1188

Oxenhandler, R. W., Adelstein, E. H., Haigh, J. P., Hook, R. R. Jr., and Clark, W. H. Jr. (1979). Malignant melanoma in the Sinclair miniature swine: an autopsy study of 60 cases. Am. J. Pathol. 96, 707-720.

Panepinto, L. M. (1996). "Miniature swine breeds used worldwide in research," in Advances in Swine in Biomedical Research, eds M. E. Tumbleson and L. B. Schook (New York, NY: Plenum Press).

Park, D. S., Cerrone, M., Morley, G., Vasquez, C., Fowler, S., Liu, N., et al. (2015). Genetically engineered SCN5A mutant pig hearts exhibit conduction defects and arrhythmias. J. Clin. Invest. 125, 403-412. doi: 10.1172/JCI 76919

Patel, A. S., Saeed, M., Yee, E. J., Yang, J., Lam, G. J., Losey, A. D., et al. (2014). Development and validation of endovascular chemotherapy filter device for removing high-dose doxorubicin: preclinical study. J. Med. Device. 8, 04100810410088. doi: $10.1115 / 1.4027444$

Pathak, S., Multani, A. S., McConkey, D. J., Imam, A. S., and Amoss, M. S. Jr. (2000). Spontaneous regression of cutaneous melanoma in sinclair swine is associated with defective telomerase activity and extensive telomere erosion. Int. J. Oncol. 17, 1219-1224.

Petersen, B., Ramackers, W., Lucas-Hahn, A., Lemme, E., Hassel, P., Queisser, A. L., et al. (2011). Transgenic expression of human heme oxygenase-1 in pigs confers resistance against xenograft rejection during ex vivo perfusion of porcine kidneys. Xenotransplantation 18, 355-368. doi: 10.1111/j.13993089.2011.00674.x

Phelps, C. J., Ball, S. F., Vaught, T. D., Vance, A. M., Mendicino, M., Monahan, J. A., et al. (2009). Production and characterization of transgenic pigs expressing porcine CTLA4-Ig. Xenotransplantation 16, 477-485. doi: 10.1111/j.13993089.2009.00533.x

Phelps, C. J., Koike, C., Vaught, T. D., Boone, J., Wells, K. D., Chen, S. H., et al. (2003). Production of alpha 1,3-galactosyltransferase-deficient pigs. Science 299, 411-414. doi: 10.1126/science.1078942

Phillips, R. W., Panepinto, L. M., Spangler, R., and Westmoreland, N. (1982). Yucatan miniature swine as a model for the study of human diabetes mellitus. Diabetes Metab. Res. Rev. 31, 30-36.

Phillips, R. W., Panepinto, L. M., Will, D. H., and Case, G. L. (1980). The effects of alloxan diabetes on Yucatan miniature swine and their progeny. Metabolism 29, 40-45. doi: 10.1016/0026-0495(80)90096-7

Polejaeva, I. A., Chen, S.-H., Vaught, T. D., Page, R. L., Mullins, J., Ball, S., et al. (2000). Cloned pigs produced by nuclear transfer from adult somatic cells. Nature 407, 86-90. doi: 10.1038/35024082

Porter, V. (1993). Pigs: A Handbook to the Breeds of the World. Ithaca, NY: Cornell University Press.

Prather, R. S., Lorson, M., Ross, J. W., Whyte, J. J., and Walters, E. (2013). Genetically engineered pig models for human diseases. Annu. Rev. Anim. Biosci. 1, 203-219.

Purohit, D. M., Swindle, M. M., Smith, C. D., Othersen, H. B. Jr., and Kazanovicz, J. M. (1993). Hanford miniature swine model for extracorporeal membrane oxygenation. J. Invest. Surg. 6, 503-508. doi: 10.3109/08941939309141640

Reger, S. I., Hyodo, A., Negami, S., Kambic, H. E., and Sahgal, V. (1999). Experimental wound healing with electrical stimulation. Artif. Organs. 23, 460-462. doi: 10.1046/j.1525-1594.1999.06365.x

Rogers, C. S., Stoltz, D. A., Meyerholz, D. K., Ostedgaard, L. S., Rokhlina, T., Taft, P. J., et al. (2008). Disruption of the CFTR gene produces a model of cystic fibrosis in newborn pigs. Science 321, 1837-1841. doi: 10.1126/science.1163600

Ropka-Molik, K., Zukowski, K., Eckert, R., Gurgul, A., Piorkowska, K., and Oczkowicz, M. (2014). Comprehensive analysis of the whole transcriptomes 
from two different pig breeds using RNA-Seq method. Anim. Genet. 45, 674684. doi: 10.1111/age.12184

Rosati, R., Horan, G. S., Pinero, G. J., Garofalo, S., Keene, D. R., Horton, W. A., et al. (1994). Normal long bone growth and development in type X collagen-null mice. Nat. Genet. 8, 129-135. doi: 10.1038/ng1094-129

Safranski, T. J. (2008). Genetic selection of boars. Theriogenology 70, 1310-1316. doi: 10.1016/j.theriogenology.2008.06.020

Sahana, G., Kadlecova, V., Hornshoj, H., Nielsen, B., and Christensen, O. F. (2013). A genome-wide association scan in pig identifies novel regions associated with feed efficiency trait. J. Anim. Sci. 91, 1041-1050. doi: 10.2527/jas.2012-5643

Sanchez, M. P., Tribout, T., Iannuccelli, N., Bouffaud, M., Servin, B., Tenghe, A., et al. (2014). A genome-wide association study of production traits in a commercial population of Large White pigs: evidence of haplotypes affecting meat quality. Genet. Sel. Evol. 46, 12. doi: 10.1186/1297-9686-46-12

Sangild, P. T., Ney, D. M., Sigalet, D. L., Vegge, A., and Burrin, D. (2014). Animal models of gastrointestinal and liver diseases. Animal models of infant short bowel syndrome: translational relevance and challenges. Am. J. Physiol. Gastrointest. Liver Physiol. 307, G1147-G1168. doi: 10.1152/ajpgi.00088.2014

Schook, L. B., Collares, T. V., Darfour-Oduro, K. A., De, A. K., Rund, L. A., Schachtschneider, K. M., et al. (2015a). Unraveling the Swine genome: implications for human health. Annu. Rev. Anim. Biosci. 3, 219-244. doi: 10.1146/annurev-animal-022114-110815

Schook, L. B., Collares, T. V., Hu, W., Liang, Y., Rodrigues, F. M., Rund, L. A., et al. (2015b). A genetic porcine model of cancer. PLOS ONE 10:e0128864. doi: 10.1371/journal.pone.0128864

Schuleri, K. H., Boyle, A. J., Centola, M., Amado, L. C., Evers, R., Zimmet, J. M., et al. (2008). The adult Gottingen minipig as a model for chronic heart failure after myocardial infarction: focus on cardiovascular imaging and regenerative therapies. Comp. Med. 58, 568-579.

Seok, J., Warren, H. S., Cuenca, A. G., Mindrinos, M. N., Baker, H. V., Xu, W., et al. (2013). Genomic responses in mouse models poorly mimic human inflammatory diseases. Proc. Natl. Acad. Sci. U.S.A. 110, 3507-3512. doi: 10.1073/pnas.1222878110

Sieren, J. C., Meyerholz, D. K., Wang, X. J., Davis, B. T., Newell, J. D. Jr., Hammond, E., et al. (2014). Development and translational imaging of a TP53 porcine tumorigenesis model. J. Clin. Invest. 124, 4052-4066. doi: 10.1172/JCI75447

Snouwaert, J. N., Brigman, K. K., Latour, A. M., Malouf, N. N., Boucher, R. C., Smithies, O., et al. (1992). An animal model for cystic fibrosis made by gene targeting. Science 257, 1083-1088. doi: 10.1126/science.257.5073.1083

Spurlock, M. E., and Gabler, N. K. (2008). The development of porcine models of obesity and the metabolic syndrome. J. Nutr. 138, 397-402.

Su, L. K., Kinzler, K. W., Vogelstein, B., Preisinger, A. C., Moser, A. R., Luongo, C., et al. (1992). Multiple intestinal neoplasia caused by a mutation in the murine homolog of the APC gene. Science 256, 668-670. doi: 10.1126/science.256.5060.1114-c

Sullivan, T. P., Eaglstein, W. H., Davis, S. C., and Mertz, P. (2001). The pig as a model for human wound healing. Wound Repair. Regen. 9, 66-76. doi: 10.1046/j.1524-475x.2001.00066.x

Swindle, M. M., Makin, A., Herron, A. J., Clubb, F. J. Jr., and Frazier, K. S. (2012). Swine as models in biomedical research and toxicology testing. Vet. Pathol. 49, 344-356. doi: 10.1177/0300985811402846

Swindle, M. M., Thompson, R. P., Carabello, B. A., Smith, A. C., Hepburn, B. J., Bodison, D. R., et al. (1990). Heritable ventricular septal defect in Yucatan miniature swine. Lab. Anim. Sci. 40, 155-161.

Takahagi, Y., Fujimura, T., Miyagawa, S., Nagashima, H., Shigehisa, T., Shirakura, R., et al. (2005). Production of alpha 1,3-galactosyltransferase gene knockout pigs expressing both human decay-accelerating factor and N-acetylglucosaminyltransferase III. Mol. Reprod. Dev. 71, 331-338. doi: $10.1002 / \mathrm{mrd} .20305$

Tank, J. C., Weiner, D. S., Jacquet, R., Childs, D., Ritzman, T. F., Horne, W. I., et al. (2013). The effects of hypothyroidism on the proximal femoral physis in miniature swine. J. Orthop. Res. 31, 1986-1991. doi: 10.1002/jor.22467

Tart, J. K., Johnson, R. K., Bundy, J. W., Ferdinand, N. N., Mcknite, A. M., Wood, J. R., et al. (2013). Genome-wide prediction of age at puberty and reproductive longevity in sows. Anim. Genet. 44, 387-397. doi: 10.1111/age.12028

Van Dyke, T. E., Hasturk, H., Kantarci, A., Freire, M. O., Nguyen, D., Dalli, J., et al. (2015). Proresolving nanomedicines activate bone regeneration in periodontitis. J. Dent. Res. 94, 148-156. doi: 10.1177/0022034514557331

van Mierlo, G. J., Cnubben, N. H., Kuper, C. F., Wolthoorn, J., Van MeeterenKreikamp, A. P., Nagtegaal, M. M., et al. (2013). The Gottingen minipig(R) as an alternative non-rodent species for immunogenicity testing: a demonstrator study using the IL-1 receptor antagonist anakinra. J. Immunotoxicol. 10, 96-105. doi: 10.3109/1547691X.2012.735274

Wakai, T., Sugimura, S., Yamanaka, K., Kawahara, M., Sasada, H., Tanaka, H., et al. (2008). Production of viable cloned miniature pig embryos using oocytes derived from domestic pig ovaries. Cloning Stem Cells 10, 249-262. doi: 10.1089/clo.2007.0045

Warman, M. L., Abbott, M., Apte, S. S., Hefferon, T., Mcintosh, I., Cohn, D. H., et al. (1993). A type X collagen mutation causes Schmid metaphyseal chondrodysplasia. Nat. Genet. 5, 79-82. doi: 10.1038/ng0993-79

West, F. D., Terlouw, S. L., Kwon, D. J., Mumaw, J. L., Dhara, S. K., Hasneen, K., et al. (2010). Porcine induced pluripotent stem cells produce chimeric offspring. Stem Cells Dev. 19, 1211-1220. doi: 10.1089/scd.2009.0458

West, F. D., Uhl, E. W., Liu, Y., Stowe, H., Lu, Y., Yu, P., et al. (2011). Brief report: chimeric pigs produced from induced pluripotent stem cells demonstrate germline transmission and no evidence of tumor formation in young pigs. Stem Cells 29, 1640-1643. doi: 10.1002/stem.713

Whitworth, K. M., Lee, K., Benne, J. A., Beaton, B. P., Spate, L. D., Murphy, S. L., et al. (2014). Use of the CRISPR/Cas9 system to produce genetically engineered pigs from in vitro-derived oocytes and embryos. Biol. Reprod. 91, 78. doi: 10.1095/biolreprod.114.121723

Whyte, J. J., and Prather, R. S. (2011). Genetic modifications of pigs for medicine and agriculture. Mol. Reprod. Dev. 78, 879-891. doi: 10.1002/mrd.21333

Xi, S., Yin, W., Wang, Z., Kusunoki, M., Lian, X., Koike, T., et al. (2004). A minipig model of high-fat/high-sucrose diet-induced diabetes and atherosclerosis. Int. J. Exp. Pathol. 85, 223-231. doi: 10.1111/j.0959-9673.2004. 00394.x

Zhao, J., Ross, J. W., Hao, Y., Spate, L. D., Walters, E. M., Samuel, M. S., et al. (2009). Significant improvement in cloning efficiency of an inbred miniature pig by histone deacetylase inhibitor treatment after somatic cell nuclear transfer. Biol. Reprod. 81, 525-530. doi: 10.1095/biolreprod.109.077016

Conflict of Interest Statement: The authors declare that the research was conducted in the absence of any commercial or financial relationships that could be construed as a potential conflict of interest.

Copyright $\odot 2015$ Gutierrez, Dicks, Glanzner, Agellon and Bordignon. This is an open-access article distributed under the terms of the Creative Commons Attribution License (CC BY). The use, distribution or reproduction in other forums is permitted, provided the original author(s) or licensor are credited and that the original publication in this journal is cited, in accordance with accepted academic practice. No use, distribution or reproduction is permitted which does not comply with these terms. 